\title{
Perbandingan Metode Isolasi DNA sebagai Templat PCR untuk Identifikasi Jenis Kelamin Cerek Jawa (Charadriius javanicus) secara Molekuler Menggunakan Primer 2550F/2718R
}

\section{Comparison of DNA Isolation Methods as PCR Template for Javan Plover (Charadriius javanicus) Molecular Sexing Using 2550F/2718R Primer Set}

\author{
Yulius Wahyu Pratomo ${ }^{1}$, Felicia Zahida ${ }^{1}$, Pramana Yuda $^{1 *}$ \\ Prodi Biologi, Fakultas Teknobiologi, Universitas Atma Jaya Yogyakarta \\ Jl. Babarsari No.44 Yogyakarta 55281 Indonesia \\ Email:pramana.yuda@uajy.ac.id *Penulis Korespondensi
}

\begin{abstract}
DNA extraction can be time consuming and costly (especially in large scale studies), therefore some studies examine the success rate of amplification using alternative DNA isolation methods (without extraction). This study aims to determine the most effective DNA isolation method in Javan Plover for molecular sexing by comparing several methods, such as extraction kit, alkaline lysis and direct PCR. This study used filter paper and EDTA stored blood as samples, and both sample types were isolated using extraction kit, alkaline lysis, and direct PCR method. PCR based molecular sexing was carried out using 2550F/2718R primer sets. The results showed that DNA in filter paper and EDTA stored blood, either using kit extraction or alkaline lysis, and direct PCR, methods were successfully amplified with $2550 \mathrm{~F} / 2718 \mathrm{R}$ primer which produced 621 bp sized CHD1-Z and 459 bp sized CHD1-W band. DNA extraction kit was the most effective DNA isolation method for providing DNA template for Javan Plover molecular sexing, that showed the most clearest bands compare to other extraction methods.
\end{abstract}

Keywords: Javan Plover, Molecular Sexing, 2550F/2718R, Extraction kit, Alkaline lysis, Direct PCR

\begin{abstract}
Abstrak
Ekstraksi DNA dapat memakan waktu dan biaya saat diterapkan dalam penelitian skala besar, sehingga beberapa studi mengkaji tingkat keberhasilan amplifikasi menggunakan metode isolasi DNA alternatif (tanpa ekstraksi). Penelitian ini bertujuan untuk mengetahui metode isolasi DNA paling efektif untuk molecular sexing Cerek Jawa. Penelitian ini menggunakan 5 sampel darah kertas saring, dan 8 sampel darah EDTA yang diisolasi dengan metode kit ekstraksi DNA, lisis alkali dan PCR langsung. PCR untuk tujuan molecular sexing dilakukan dengan menggunakan primer 2550F/2718R. Hasil penelitian menunjukan bahwa DNA pada sampel darah kertas saring dan EDTA yang diisolasi baik menggunakan kit ektraksi DNA, lisis alkali maupun PCR langsung, berhasil diamplifikasi dengan primer 2550F/2718R yang menghasilkan pita CHD1-Z dengan ukuran 621 bp dan pita CHD1-W dengan ukuran 459 bp, namun kualitas pita DNA yang dihasilkan berbeda. Metode Isolasi DNA dengan kit ekstraksi menghasilkan DNA templat yang paling efektif untuk molecular sexing Cerek Jawa karena pita DNA hasil amplifikasi lebih jelas dibanding metode yang lain.
\end{abstract}

Kata Kunci: Cerek Jawa, Molecular Sexing, 2550F/2718R, Kit ekstraksi DNA, Alkalin Lisis, PCR Langsung

Diterima: 12 Februari 2020, disetujui: 7 Mei 2020

\section{Pendahuluan}

Ekstraksi DNA telah diterapkan pada berbagai studi molekuler untuk mendapatkan
DNA serta menyingkirkan inhibitor dari sampel. Namun, ekstraksi memiliki kekurangan seperti menggunakan bahan mudah terbakar, korosif, toksik serta memakan 
waktu dan biaya saat diterapkan dalam penelitian skala besar (Khatib et al., 1993; Tan dan Yiap, 2009). Menyikapi kekurangan tersebut, beberapa studi molekuler diterapkan tanpa melalui ektraksi atau menggunakan metode isolasi DNA alternatif. Contohnya Alessandra et al. (2002), berhasil mengidentifikasi jenis kelamin 12 spesies dari 3 ordo burung menggunakan metode alkalin lisis. Terdapat beberapa studi molecular sexing lain yang membandingkan tingkat keberhasilan berbagai metode isolasi DNA, tetapi sedikit studi yang menerapkannya pada spesies lokal Indonesia, contohnya Cerek Jawa.

Cerek Jawa (Charadrius javanicus) merupakan burung pantai endemik Indonesia yang berhabitat di pulau Jawa, Kangean dan Bali (Howes et al., 2003; Kurniawan dan Arifianto, 2017). Meski Birdlife International (2018), memasukan Cerek Jawa ke dalam Near Threatened, Iqbal et al. (2013), menyatakan bahwa status burung ini dapat berubah menjadi 'Vulnerable'. Selain itu, berdasarkan Peraturan Menteri Lingkungan Hidup dan Kehutanan Republik Indonesia Nomor P.92/MENLHK/SETJEN/KUM.1/8/2018

tentang Jenis Tumbuhan dan Satwa yang Dilindungi, Cerek Jawa telah ditetapkan sebagai salah satu satwa yang dilindungi. Studi lebih lanjut sangat penting untuk membantu usaha konservasi spesies ini.

Studi ini bertujuan untuk mengetahui metode isolasi DNA yang paling efektif dalam molecular sexing Cerek Jawa dengan membandingkan hasil PCR dari templat DNA hasil isolasi dengan kit ekstraksi DNA, lisis alkali dan PCR langsung. Kajian molecular sexing dapat menentukan jenis kelamin secara pasti, sehingga sangat diperlukan untuk keberhasilan reproduksi satwa (Cerek Jawa) dalam program konservasi (Çakmak et al., 2017). Selain itu, adanya perbandingan metode isolasi DNA dapat memberikan pilihan alternatif yang minim waktu serta biaya dalam molecular sexing, terutama dalam studi berskala besar (Dhanasekaran et al., 2016).

\section{Metode Penelitian}

\section{Alat dan Bahan}

Alat yang digunakan adalah scalpel, blade, microcentrifuge tube, mikropipet, mikrotip, timbangan analisis, waterbath, tray, comb, vortex, Spindown, bunsen, petridisk, PCR tube, erlemeyer, oven, elektroforesis, thermal cycler, dark reader, dan Spektrofotometer Nano Vue.

Bahan yang digunakan adalah PBS Buffer, ethanol absolut, $\mathrm{NaOH} 50 \mathrm{Mm}$, Tris$\mathrm{HCl} 1 \mathrm{M}, \mathrm{gSNYC}^{\mathrm{TM}}$ DNA Extraction Kit (Geneaid), $\mathrm{ddH}_{2} \mathrm{O}$, primer 2550F/2718R, buffer KOD, dNTPs, KOD Fx Neo

(Toyobo Co, 2013), gel agarosa, buffer TBE $0.5 \mathrm{x}$, ethidium bromide $1 \%$, loading dye, DNA ladder (100 bp), GST Buffer, Proteinase K, GSB Buffer, W1 buffer, wash buffer, elution buffer, XPDF Buffer dan XPDF Wash Buffer, dan parafilm. Terdapat 2 jenis sampel Cerek Jawa yang digunakan, yaitu darah kertas saring (TR 1094, TR 1103, TR 1105, TR 1107, dan Cer J 14) dan darah EDTA (Cer J 1, Cer J 2, Cer J 4, Cer J 13, AF 004, AF 007, TR 1022, dan WJ 1209). DNA seluruh sampel diisolasi dengan metode kit ekstraksi DNA, lisis alkali, dan PCR langsung.

\section{Prosedur Kerja}

\section{Kit ekstraksi DNA}

Proses ekstraksi mengikuti protokol yang disarankan dengan gSYNC ${ }^{\mathrm{TM}}$ DNA Extraction Kit (Geneaid) dan. Tahap lysis sampel darah kertas saring adalah kertas saring dipotong 5 x $5 \mathrm{~mm}$, dimasukan ke microcentrifuge tube, lalu ditambah $200 \mu \mathrm{l}$ GST buffer dan $20 \mu$ proteinase K, kemudian di-vortex. Sampel diinkubasi dalam waterbath pada suhu $60{ }^{\circ} \mathrm{C}$ selama 30 menit. Supernatan dipindahkan ke dalam microcentrifuge tube kemudian ditambah $200 \mu$ l GSB buffer, lalu di-vortex selama 10 detik. Tahap lysis sampel darah dalam EDTA dilakukan dengan mengambil sampel darah sebanyak $20 \mu \mathrm{l}$, dimasukan ke microcentrifuge tube, ditambah $180 \mu 1$ PBS buffer, kemudian ditambah $20 \mu 1$ proteinase $\mathrm{K}$ serta di-vortex selama 15 detik. Campuran tersebut lalu diinkubasi dalam waterbath pada suhu $60^{\circ} \mathrm{C}$ selama 5 menit. Selanjutnya ditambahkan $200 \mu \mathrm{l}$ GSB buffer, kemudian di-vortex selama 15 detik, dan sampel diinkubasi kembali dalam waterbath pada suhu $60{ }^{\circ} \mathrm{C}$ selama 5 menit (invert setiap 2 menit).

Setelah tahap lysis sel, sampel kertas saring dan darah dalam EDTA diperlakukan proses DNA binding dengan tahap yang sama. Sampel diberi $200 \mu \mathrm{l}$ ethanol absolute $(99,5 \%)$ 
dan divortex 10 detik. GS column diletakan ke dalam collection tube, lalu semua sampel dipindahkan kedalam GS column. Sampel disentrifugasi $14.000 \mathrm{rpm}$ selama 1 menit lalu cairan dalam Collection tube dibuang. GS collum dipindahkan ke dalam collection tube baru.

Selanjutnya adalah pencucian (wash), yaitu $400 \mu \mathrm{l}$ W1 buffer dimasukan ke dalam GS collum (yang mengandung sampel), lalu GS column disentrifugasi $14000 \mathrm{rpm}$ selama 30 detik. Cairan dalam collection tube dibuang, kemudian GS collum diletakan kembali dalam collection tube sebelumya. Sebanyak $600 \mu \mathrm{l}$ wash buffer ditambahkan ke dalam GS column dan GS column disentrifugasi $14.000 \mathrm{rpm}$ selama 30 detik. Cairan dalam collection tube di buang dan $G S$ collumn diletakan kembali dalam collection tube. GS column lalu disentrifugasi 14.000 rpm selama 5 menit (pengeringan kolom). Selama sentrifugasi berlangsung, sebanyak 210 $\mu 1$ elution buffer dimasukan ke dalam microcentrifuge tube $2 \mathrm{ml}$ baru dan diinkubasi suhu $60^{\circ} \mathrm{C}$ selama 5 menit untuk proses elusi.

Tahap elusi dilakukan sebanyak 3 kali dan memiliki beberapa langkah. GS column diletakan dalam microsentrifuge tube baru, kemudian GS column ditambah $50 \mu$ l elution buffer tepat di tengah kolom. GS column lalu didiamkan selama 3 menit, kemudian disentrifugasi $14.000 \mathrm{rpm}$ selama 30 detik. Pengukuran kualitas dan kuantitas DNA dilakukan dengan Spectrofotometer NanoVue.

\section{Lisis Alkali}

Sampel kertas saring $(5 \times 5 \mathrm{~mm})$ dan sample darah EDTA $(20 \mu \mathrm{l})$ dimasukan ke dalam microcentrifuge tube, kemudian ditambahkan $180 \quad \mu l \quad \mathrm{NaOH} \quad 50 \quad \mathrm{mM}$ lalu divortex 15 detik. Sampel lalu diinkubasi dalam waterbath suhu $95{ }^{\circ} \mathrm{C}$ selama 10 menit dan ditambah $20 \mu \mathrm{l}$ Tris-HCl $1 \mathrm{M}$ (PH 8), lalu divortex, kemudian disentrifugasi $12.000 \mathrm{rpm}$ selama 5 menit.

\section{PCR Langsung}

Proses PCR langsung dilakukan dengan sampel darah kertas saring dipotong sekecil mungkin $(1 \times 1 \mathrm{~mm})$, sedangkan sampel darah EDTA diambil sebanyak $1 \mu$ l. Kedua sampel tersebut digunakan sebagai templat PCR.

Tabel 1. Komposisi PCR Master mix KOD Fx Neo

\begin{tabular}{|c|c|}
\hline Reagen & 1. $\mathrm{x}$ reaksi (Total Volume $10 \mu \mathrm{l})$ \\
\hline ddd $\mathrm{d}_{2} \mathrm{O}$ (PCR grade water) & $1,2 \mu l$ \\
\hline 2x Buffer KOD Fx Neo & $5 \mu 1$ \\
\hline $2 \mathrm{mM}$ dNTPs & $2 \mu 1$ \\
\hline Primer F & $0,3 \mu \mathrm{l}$ \\
\hline Primer R & $0,3 \mu 1$ \\
\hline KOD Fx Neo $1.0 \mathrm{U} / \mu \mathrm{l}$ (DNA pol) & $0,2 \mu \mathrm{l}$ \\
\hline DNA Template & $1 \mu \mathrm{l}$ \\
\hline Total Volume & $10 \mu 1$ \\
\hline
\end{tabular}

Tabel 2. Siklus PCR (40 siklus)

\begin{tabular}{lccc}
\hline & Tahap & Suhu $\left({ }^{\circ} \mathrm{C}\right)$ & Waktu \\
\hline \hline Predenaturasi & 94 & 2 menit \\
Denaturasi & 98 & 15 detik \\
Annealing & 53 & 30 detik \\
Extention & 68 & 45 detik \\
Final Extention & 68 & 7 menit \\
Hold & 4 & $\infty$ \\
\hline \hline
\end{tabular}

(Wulansari et al., 2013)

\section{Amplifikasi CHD1}

$\begin{array}{llr}\text { Amplifikasi CHD1 Cerek } & \text { Jawa } \\ \text { dilakukan dengan primer } & \text { 2550F } \\ \text { (GTTACTGATTCGTCTACGAGA) dan } & \text { 2718R } \\ \text { (ATTGAAATGATCCAGTGCTTG) } & \end{array}$

(Fridolfsson \& Ellegren, 1999) dan KOD Fx Neo (Toyobo Co, 2013). Selain itu, kondisi siklus thermal cycler disesuaikan dengan protokol KOD Fx Neo dan Ta primer. Komposisi basa nukleotida primer, master mix 
KOD Fx Neo, serta kodisisi siklus dapat dilihat dalam Tabel 1 \& 2.

Visualisasi hasil amplifikasi dilakukan dengan gel agarosa $2 \%$, buffer TBE $0.5 x$. Gel stain yang digunakan adalah ethidium bromide $1 \%$. Elektroforesis dilakukan running pada kondisi 100 volt $(5$ volt $/ \mathrm{cm})$ selama 30 menit.

\section{Sekuensing Gen CHD1-W dan CHD1-Z}

Tahap sekuensing memiliki persiapan berupa amplifikasi big volume dan purifikasi gel agarosa. Amplifikasi big volume memiliki kondisi yang sama dengan amplifikasi CHD1 Cerek Jawa, sedangkan purifikasi gel agarosa dilakukan dengan kit Xprep Gel and PCR Purification Kit (PhileKorea). Sekuensing CHD1-Z (sampel Cer J 1) dan CHD1-W (sampel Cer J 13) dilakukan dengan mengirimkan hasil purifikasi gel ke Lab $1^{\text {st }}$ BASE Sequencing Sdn Bhd, Malaysia.

\section{Hasil dan Pembahasan}

\section{A. Hasil Uji Kuantitas dan Kualitas DNA Template dari Kit ekstraksi DNA}

Uji kuantifikasi menunjukan adanya variasi nilai rasio OD (optical dencity) A260/A280, A260/A230 dan konsentrasi DNA. Nilai OD A260/A280 memiliki kisaran 1,59 - 2,709, sedangkan OD A260/A230 memiliki kisaran 0,347 - 2,128. Konsentrasi DNA hasil ekstraksi memiliki kisaran 1,038 $58 \mathrm{ng} / \mu \mathrm{l}$ (Tabel 3).

DNA hasil ekstraksi memiliki kualitas yang murni apabila rasio OD A260/A280 menunjukan nilai 1,8-2,00. Jika OD A260/A280 menunjukkan nilai di bawah 1,8, maka DNA hasil ekstraksi memiliki kontaminasi protein atau fenol. Namun, jika OD A260/A280 menunjukan nilai di atas 2,0, maka DNA hasil ekstraksi memiliki kontaminasi RNA (Glasel, 1995).

Tabel 3. Kuantitas dan kualitas ekstraksi DNA darah dalam kertas saring dan EDTA Cerek Jawa dengan gSYNC ${ }^{\mathrm{TM}}$ DNA Extraction Kit

\begin{tabular}{|c|c|c|c|c|}
\hline Kode Sampel & Kondisi Sampel & A260/A230 & A260/A280 & Konsentrasi $(\mathrm{ng} / \mu \mathrm{l})$ \\
\hline TR 1094 & Kertas saring & 1,963 & 1,824 & 23,616 \\
\hline TR 1103 & Kertas saring & 0,706 & 1,729 & 4,909 \\
\hline TR 1105 & Kertas saring & 1,993 & 1,993 & 2,093 \\
\hline TR 1107 & Kertas saring & 0,517 & 1,59 & 1,038 \\
\hline Cer J 14 & Kertas saring & 1,793 & 1,793 & 19,25 \\
\hline Cer J 1 & EDTA & 2,128 & 1,758 & 58 \\
\hline Cer $\mathbf{J} 2$ & EDTA & 1,894 & 1,667 & 14,05 \\
\hline Cer J 4 & EDTA & 1,8765 & 1,692 & 9,786 \\
\hline Cer J 13 & EDTA & 2,048 & 1,825 & 34,5 \\
\hline AF 004 & EDTA & 0,477 & 1,978 & 3,683 \\
\hline AF 007 & EDTA & 0,72 & 2,258 & 3,561 \\
\hline TR 1022 & EDTA & 0,347 & 2,709 & 1,326 \\
\hline WJ 1209 & EDTA & 0,5223 & 1,811 & 5,037 \\
\hline
\end{tabular}

Berdasarkan rasio OD A260/A280, diketahui beberapa sampel (AF007, TR1022) mengalami kontaminasi protein dan RNA. Salah satu penyebab kontaminasi protein pada beberapa sampel, kemungkinan karena adanya penyumbatan kolom oleh serat kertas saring maupun protein yang belum tercerna sepenuhnya (Latif \& Osman, 2017). Sementara kontaminasi RNA dapat terjadi karena RNA belum terhidrolisis sepenuhnya. RNA relatif lebih mudah terhidrolisis dibanding DNA sebab mengandung gula ribose, tetapi ada kemungkinan bahwa RNA tidak terhidrolisis sepenuhnya sehingga menyisakan residu RNA (Sah et al., 2014).
Berdasarkan rasio OD A260/A230, DNA hasil ekstraksi memiliki kualitas yang murni apabila menunjukan nilai 2,3-2,4. (Liu et al., 2009). Seluruh sampel memiliki nilai < 2,3 yang menunjukan adanya kontaminasi garam chaotropic (guanidine) dan deterjen non-ionik. Kedua bahan ini biasa digunakan dalam kit ekstraksi sehingga ada kemungkinan ikut mengontaminasi hasil kit ekstraksi DNA (Koetsier dan Cantor, 2019).

\section{B. Hasil Amplifikasi Terhadap Sampel Kertas Saring}

Berdasarkan identifikasi dengan Geldoc, individu betina menghasilkan pita CHD1-Z 
berukuran 641 bp dan pita CHD-W berukuran 476 bp, sedangkan individu jantan menghasilkan pita CHD1-Z berukuran $641 \mathrm{bp}$. Menurut Fridolfsson dan Ellegren (1999), primer $2550 \mathrm{~F} / 2718 \mathrm{R}$ menghasilkan fragmen
CHD1-W berukuran $400-450$ bp, serta fragmen CHD1-Z berukuran 600 - 650 bp. Visualisasi produk PCR terhadap metode kit ekstraksi DNA dan lsiis alkali ditunjukan pada Gambar 1.

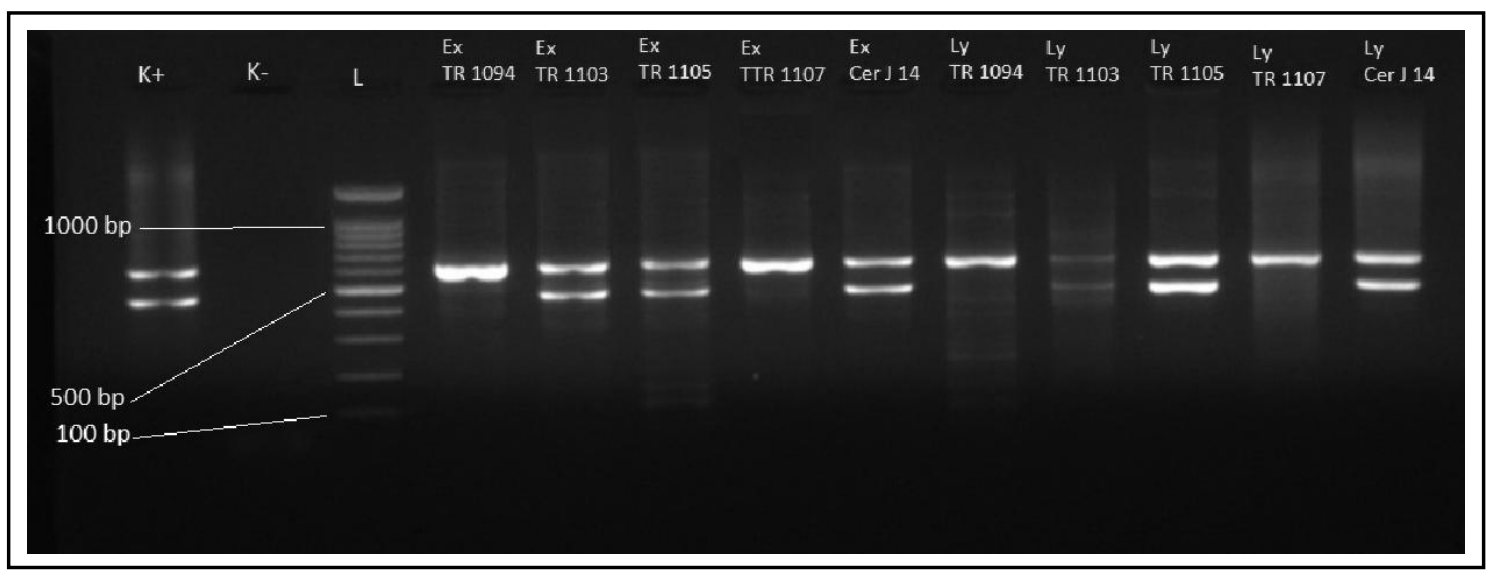

Gambar 1. Visualisasi produk PCR DNA Cerek Jawa dari sampel darah kertas saring. dengan DNA template hasil isolasi metode kit ekstraksi DNA dan lisis alkali menggunakan primer 2550F/2718R: Ex) Kit ekstraksi DNA; Ly) Lisis alkali (K: Kontrol, L: Ladder).

Proses PCR DNA template hasil isolasi DNA dengan metode kit ekstraksi DNA berhasil mengamplifikasi seluruh sampel kertas saring dengan pita terlihat jelas dan memiliki sedikit smear (Gambar 1). Keberhasilan amplifikasi gen CHD1 pada sampel kertas saring disebab oleh keberhasilan ekstraksi dalam mengisolasi DNA dari inhibitor. Smear yang terbentuk pada produk amplifikasi dapat diminimalisir dengan mengurangi siklus PCR dan memperpendek waktu ekstensi (Rapley, 2000).

Proses amplifikasi DNA template hasil isolasi DNA dengan metode lisis alkali menghasilkan pita yang jelas pada sampel TR 1094,TR 1105, TR 1107, dan Cer J 14, sedangkan sampel TR 1103 memiliki pita yang redup (faint). Pita redup pada TR 1103 dapat disebabkan oleh inhibitor dalam reaksi PCR seperti hemoglobin dan immunoglobulin. Hemoglobin menghambat reaksi amplifikasi dengan cara mengganggu aktivitas DNA polimerase. Inhibisi hemoglobin dapat diminimalisir dengan penggunaan enzim proteinase K (Ebeling et al., 1974; Sidstedt et al., 2018). Berbeda dengan hemoglobin, immunoglobulin $G$ akan membentuk ikatan dengan DNA genom, sehingga penempelan primer maupun DNA polimerase terhambat. Efek IgG akan bersifat kuat jika templat berwujud ssDNA (Sidstedt et al., 2018). Visualisasi produk PCR menggunakan metode PCR langsung ditunjukan Gambar 2.

Gambar 2 menunjukan hasil amplifikasi PCR langsung yang jelas pada sampel TR 1103, TR 1105 dan Cer J 14, sedangkan sampel TR 1094 dan TR 1107 menghasilkan smear tebal. Menurut Jennings (2017), smear terbentuk karena konsentrasi DNA templat terlalu tinggi sehingga terjadi overamplification. Tingginya konsentrasi DNA dapat disebabkan oleh pekatnya volume darah dalam kertas saring.

\section{Hasil Amplifikasi Terhadap Sampel Darah dalam EDTA}

Proses PCR DNA template hasil isolasi dengan metode kit ekstraksi DNA berhasil mengamplifikasi seluruh sampel darah EDTA dengan pita terlihat jelas dan memiliki sedikit smear (Gambar 3). Keberhasilan amplifikasi gen CHD1 pada sampel darah EDTA disebabkan oleh keberhasilan tahap ekstraksi dalam mengisolasi DNA. Smear yang terbentuk pada produk amplifikasi dapat diminimalisir dengan mengurangi jumlah siklus PCR dan memperpendek waktu ekstensi (Rapley, 2000). Visualisasi produk PCR terhadap metode lisis alkali ditunjukan Gambar 4. 


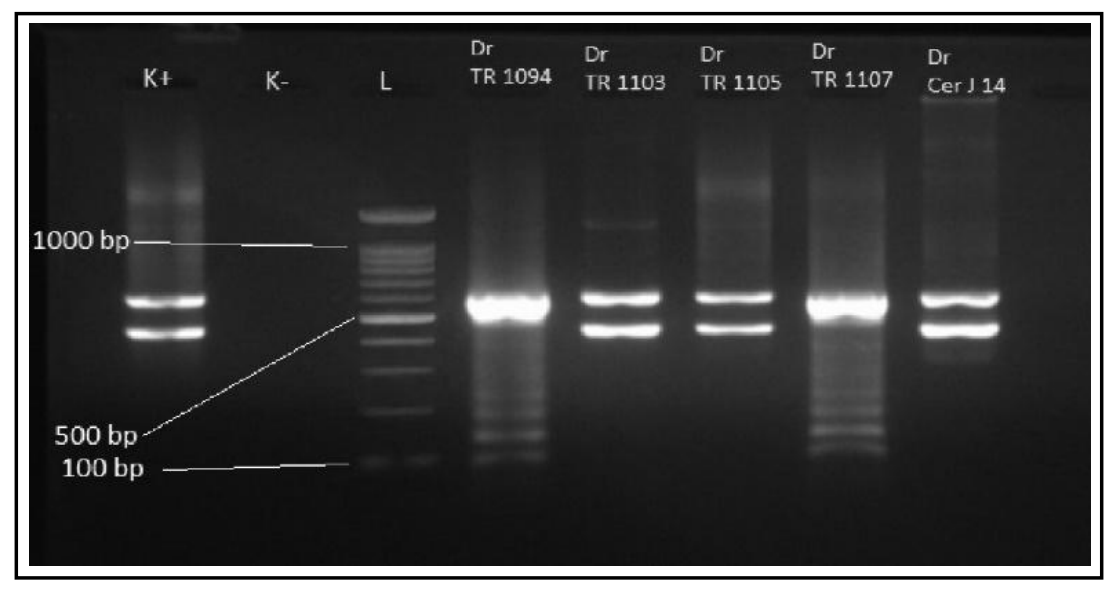

Gambar 2. Visualisasi produk PCR DNA Cerek Jawa dari sampel kertas saring menggunakan metode PCR langsung dengan primer 2550F/2718R (K: Kontrol, L: Ladder).

Proses amplifikasi DNA template hasil isolasi dengan metode lisis alkali (Gambar 4) menghasilkan pita yang jelas pada sampel Cer J 1, Cer J 2, Cer J 4, Cer J 13 AF 004, TR 1107, dan WJ 1209, sedangkan sampel AF 007 menunjukan pita yang redup (faint). pita redup (faint band) pada sampel AF 007 dapat disebabkan oleh inhibitor hemoglobin maupun immunoglobulin G. Hemoglobin bekerja dengan mengganggu aktivitas enzim DNA polimerase selama proses PCR, sedangkan Immunoglobulin $\mathrm{G}$ ( $\mathrm{IgG}$ ) berkerja dengan mengikat DNA genom, sehingga menghambat penempelan primer maupun DNA polimerase (Sidstedt et al., 2018). Visualisasi produk PCR terhadap metode PCR langsung ditunjukan Gambar 5.

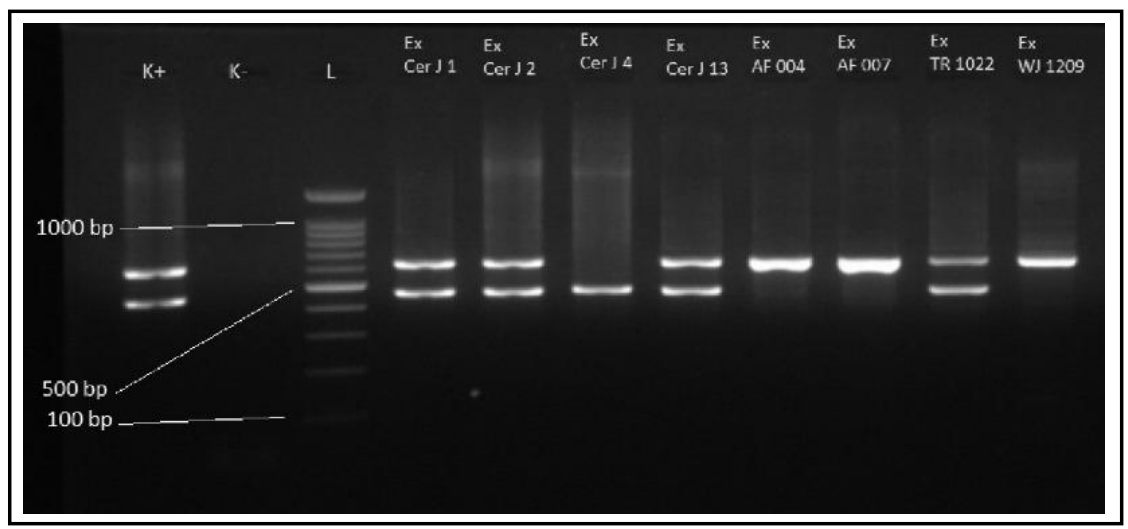

Gambar 3. Visualisasi produk PCR DNA Cerek Jawa dari sampel darah dalam EDTA dengan DNA template hasil isolasi metode kit ekstraksi DNA menggunakan primer 2550F/2718R (K: Kontrol, L: Ladder).

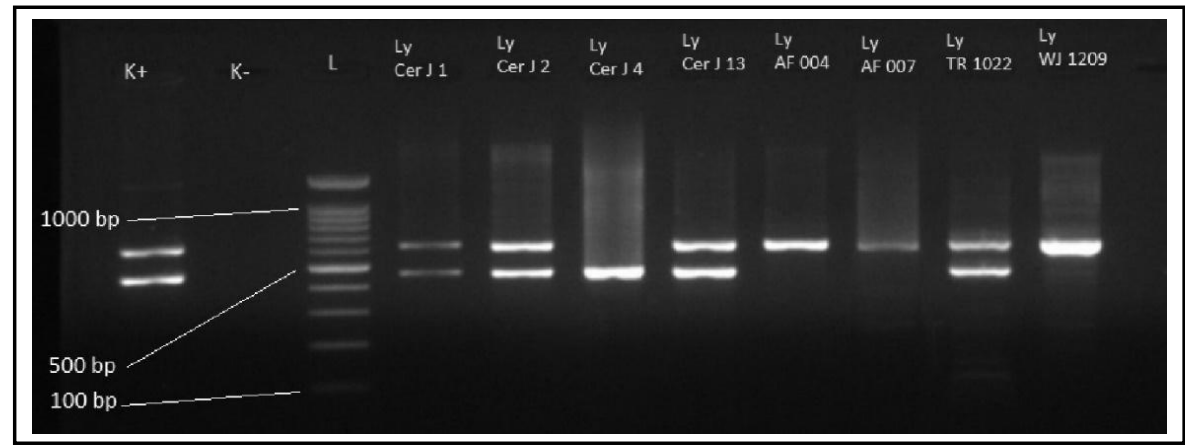

Gambar 4. Visualisasi produk PCR Cerek Jawa metode alkalin lisis sampel darah dalam EDTA dengan primer 2550F/2718R. (K:Kontrol,L:Ladder). 


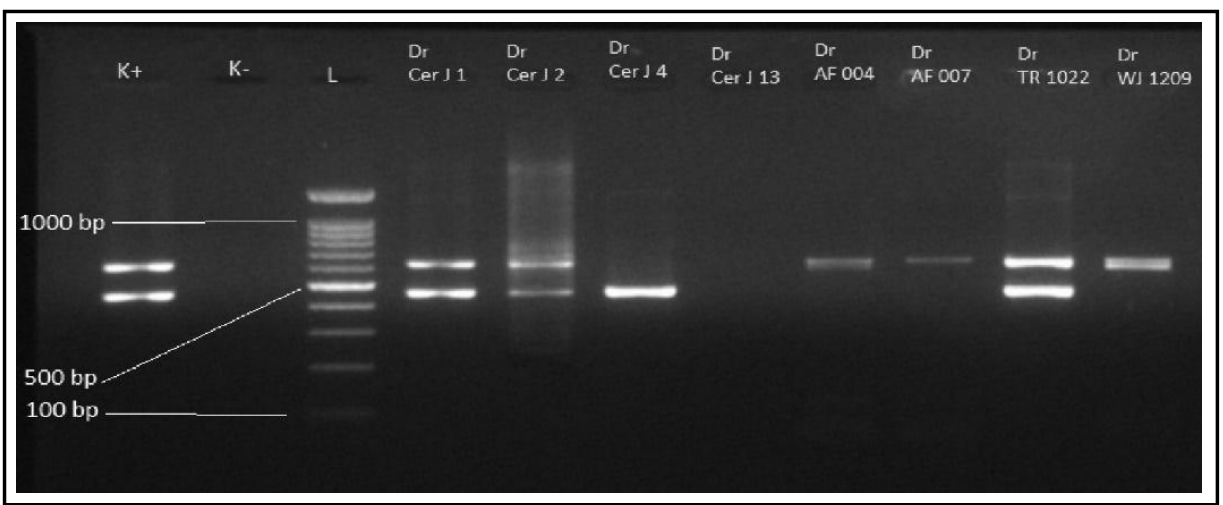

Gambar 5. Visualisasi produk PCR Cerek Jawa PCR langsung pada sampel darah dalam EDTA dengan primer 2550F/2718R (K: Kontrol, L: Ladder).

Isolasi metode PCR langsung menghasilkan pita jelas pada sampel Cer J 1, Cer $\mathbf{J} 4$ dan TR 1022, pita redup pada sampel Cer J 2, AF 004 dan AF 007, serta sampel Cer J 13 tidak menghasilkan pita. Selain inhibitor dari sampel darah (hemoglobin dan immunoglobulin G), pita redup serta nihilya pita dapat disebabkan oleh antikoagulan/EDTA. EDTA menghambat proses amplifikasi dengan mengkhelatkan ion (logam) $\mathrm{Mg}^{2+}$ (kofaktor DNA polimerase). Terkhelatkannya ion $\mathrm{Mg}^{2+}$ menyebabkan DNA polimerase tidak memiliki kofaktor, sehingga kinerja amplifikasi dapat menurun/terhenti (Rossen et al., 1992).

Penyebab lain adalah konsentrasi gel agarosa yaitu 2\%. Menurut Lee et al. (2012), semakin tinggi konsentrasi agarosa, maka semakin kecil pula ukuran pori di dalam matriks agarosa, sehingga pergerakan DNA semakin sulit/terhambat. Konsentrasi agarosa dapat diturunkan menjadi 1,5\%.

Sampel Cer J 4 (darah EDTA) hanya menghasilkan 1 pita berukuran 476 bp yang mengindikasikan teramplifikasinya fragmen CHD1-W, namun fragmen CHD1-Z tidak teramplifikasi. Terbentuknya hanya 1 pita CHD1-W pada sampel ini, juga ditemukan pada reaksi yang menggunakan DNA templat hasil isolasi DNA metode kit ekstraksi DNA, alkalin lisis dan PCR langsung. Peristiwa ini dapat disebut allelic dropout (ADO), yaitu gagalnya proses amplifikasi suatu alel dalam reaksi PCR (Stevens et al., 2017).

\section{Sekuensing CHD1-Z dan CHD1-W}

Berdasarkan hasil sekuensing, primer 2550F/2718R diperoleh fragmen CHD1-Z berukuran 621 bp dan fragmen CHD1-W berukuran 459 bp pada Cerek Jawa. Insee et al. (2014), mengungkapkan bahwa secara spesifik, primer 2550F/2718R akan mengamplifikasi parsial ekson 15, intron 15 dan parsial ekson 16. Perbedaan panjang kedua fragmen berasal dari perbedaan panjang intron.

\section{Simpulan}

Metode isolasi DNA yang paling efektif dalam molecular sexing Cerek Jawa adalah menggunakan kit ekstraksi DNA, karena seluruh sampel mampu menghasilkan templat DNA yang dapat diamplifikasi. Metode alkalin lisis kurang efektif dalam molecular sexing Cerek Jawa, karena templat DNA yang dihasilkan beberapa sampel memiliki pita redup. Metode PCR langsung juga kurang efektif dalam molecular sexing Cerek Jawa, karena templat DNA yang dihasilkan oleh salah satu sampel tidak dapat diamplifikasi.

Penelitian lanjutan perlu dilakukan pada teknik elektroforesis, yaitu dengan menggunakan konsentrasi agarosa yang lebih kecil (misalnya 1,5 \%) untuk memudahkan pergerakan DNA dan menambah jumlah amplikon untuk memperjelas sampel yang berpita redup, serta untuk memastikan penyebab tidak munculnya pita pada Cer J 13 apakah disebabkan oleh kegagalan amplifikasi atau amplikon yang terlalu sedikit.

\section{Ucapan Terima Kasih}

Penulis mengucapkan terima kasih kepada pihak Laboratorium Balai Besar 
Penelitian Bioteknologi dan Pemuliaan Tanaman Hutan, Purwobinangun di Pakem, Sleman, D.I. Yogyakarta yang turut berperan dalam menyediakan sampel, alat, dan bahan selama penelitian berlangsung.

\section{Daftar Pustaka}

Alessandra, M.T., Sílvia, N.D.L. dan Cristiano, D. . (2002). Molecular method of sexing waterbirds without DNA extraction. Waterbirds, 25(2), 245-248. https://doi.org/10.1675/1524-4695(2002)025

Birdlife, I. (2018). Species factsheet: Charadrius javanicus.

Çakmak, E., Pekşen, C. A., dan Bilgin, C. C. (2017). Comparison of three different primer sets for sexing birds. Journal of Veterinary Diagnostic Investigation, 29(1), 59-63. https://doi.org/10.1177/1040638716675197

Co, T. (2013). Instruction manual for KOD FX Neo 1103.

Dhanasekaran, S., Dhinakar, R.G., Vignesh, A.R., Selvan, S.T., Prakash, B., Perumal, P., Arivudainambi, S. dan Babu, T. . (2016). Gender identificationin chicken (Gallus gallus) by PCR using whole blood and driedblood spot on filter paper as template: without prior DNA isolation. BioRxiv, 046888, 1-15.

Ebeling, W., Hennrich, N., Klockow, M., Metz, H., Orth, H.D. dan Lang, H. (1974). Proteinase K from Tritirachium Album Limber. European Journal of Biochemistry, 47(1), 91-97.

Fridolfsson, A. dan Ellegren, H. (1999). A simple and universal method for molecular sexing of non-ratite birds. Journal of Avian Biology, 30(1), 116-121. https://doi.org/10.2307/3677252

Glasel, J. (1995). Validity of nucleic acid purities monitored by $260 \mathrm{~nm} / 280 \mathrm{~nm}$ absorbance ratios. BioTechniques, 18(1), 62-63.

Howes, J., Bakewell, D. dan Rusila, N. . (2003). Panduan Studi Burung Pantai. Wetlands International - Indonesia Programme, Bogor.

Indonesia, M. L. H. dan K. R. (n.d.). Peraturan Menteri Lingkungan Hidup dan Kehutanan Republik Indonesia Nomor P.92/MENLHK/SETJEN/KUM.1/8/2018

Perubahan Atas Peraturan Menteri Lingkungan Hidup dan Kehutanan Nomor P.20/MENLHK/SETJEN/KUM.1/6/2018

Tentang Jenis Tumbuhan dan Satwa Yang
Dilindung.

Insee, J., Kalmolnorratnath, S., Baicharoen, S., Chumpadang, S., Sawasu, W., dan Wajjwalku, W. (2014). PCR-based method for sex identification of Eastern Sarus Crane (Grus Antigone sharpie): Implications for reintroduction programs in Thailand. Zoological Science, 31(2), 95-100. https://doi.org/10.2108/zsj.31.95

Iqbal, M., Taufiqurrahman, I., Yordan, K. dan Balen, B. . (2013). The distribution, abundance and conservation status of the Javan Plover Charadrius javanicus. Wader Study Group Bulletin, 120(1), 75-79.

Jennings, W. B. (2017). Phylogenomic Data Acquisition: Principles and Practice. CRC Press.

Khatib, H., Genislav, E., Crittenden, L.B., Bumstead, N. dan Soller, M. (1993). Sequence-tagged microsatellite sites as markers in chicken reference and resource populations. Animal Genetics, 24(5), 355362.

Koetsier, G., \& Cantor, E. (2019). A practical guide to analyzing nucleic acid concentration and purity with microvolume spectrophotometers.

Kurniawan, N. dan Arifianto, A. (2017). Ornitologi: Sejarah, Biologi dan Konservasi. Universitas Brawijaya Press, Malang.

Latif, A., \& dan Osman, G. (2017). Comparison of three genomic DNA extraction methods to obtain high DNA quality from maize. Plant Methods, 13(1), 1-9. https://doi.org/10.1186/s13007-016-0152-4

Lee, P.Y. Costumbrado, J., Hsu, C.Y. dan Kim, Y. . (2012). Agarose gel electrophoresis for the separation of DNA fragments. Journal of Visualized Experiments, 62(1), 1-5. https://doi.org/10.3791/3923

Liu, P. F., Avramova, L. V., \& Park, C. (2009). Revisiting absorbance at $230 \mathrm{~nm}$ as a protein unfolding probe. Analytical Biochemistry, 389(2), 165-170. https://doi.org/10.1016/j.ab.2009.03.028

Rapley, R. (2000). The Nucleic Acid Protocols Handbook. Humara Press.

Rossen, L., Nørskov, P., Holmstrøm, K. dan Rasmussen, O. . (1992). Inhibition of PCR by components of food samples, microbial diagnostic assays and DNA-extraction solutions. International Journal of Food Microbiology, 17(1), 37-45.

Sah, S. K., Kaur, G., dan Kaur, A. (2014). Rapid 
and reliable method of high-quality RNA extraction from diverse plants. American Journal of Plant Sciences, 5(1), 3129-3139. https://doi.org/10.4236/ajps.2014.521329

Sidstedt, M., Hedman, J., Romsos, E.L., Waitara, L., Wadsö, L., Steffen, C.R., Vallone, P.M. dan Rådström, P. (2018). Inhibition mechanisms of hemoglobin, immunoglobulin $G$, and whole blood in digital and real-time PCR. 410, 2569-2583.

Stevens, A.J., Taylor, M.G., Pearce, F.G. dan Kennedy, M. . (2017). Allelic dropout during polymerase chain reaction due to G- quadruplex structures and DNA methylation is widespread at imprinted human loci. G3 (Bethesda), 7(3), 1019-1025. https://doi.org/10.1534/g3.116.038687

Tan, S.C. dan Yiap, B. . (2009). DNA, RNA, and protein extraction: The past and the present. Journal of Biomedicine and Biotechnology, $1(1)$, $1-10$. https://doi.org/10.1155/2009/574398

Wulansari, W., Yuda, P. dan Zahida, F. (2013). Uji efektifitas gen CHD sebagai penanda molekuler untuk identifikasi jenis kelamin pada burung air. E-Journal UAJY. 